surgeon in the Army or Navy, dealing with medicine, surgery, or military hygiene.

Physiology.-The Montyon prize ( 750 francs), for the most useful work on experimental physiology; the Lallemand prize (I80o francs), to recompense or encourage work relating to the nervous system; the $\mathrm{L}$. La Caze prize (10,000 francs), for the work which has most contributed to the progress of physiology (the prize cannot be divided, and foreigners can compete); the Pourat prize (1000 francs), for the experimental study of some of the conditions which produce a variation in the quantity of water in different tissues; the Mantin-Damourette prize (I400 francs), for therapeutic physiology; the Philipeaux prize ( 900 francs), for experimental physiology.

Statistics.-The Montyon prize (rooo francs) and two mentions (500 francs), for statistical researches.

History and Philosophy of Science.-The Binoux prize (2000 francs).

Medals.-The Arago, Lavoisier, and Berthelot medals.

General Prizes.-Prize founded by the State (300o francs), question for 1918 : to improve in an important point the study of the successive powers of the same substitution, the exponent of the power increasing indefinitely; the Bordin prize (3000 francs), for a study of the effects of pressure on chemical combinations in general, and in particular on those which are susceptible of a practical application; the Estrade-Delcros prize ( 8000 francs, undivided), for work in the physical sciences; the Le Conte prize (50,000 francs ; encouragements), one-eighth for encouragements, the whole or part of the remaining seven-eighths in a single prize for new and capital discoveries in mathematics, physics, chemistry, natural history, medicine, or for new applications of these sciences; the Houllevigue prize (5000 francs), for work in mathematics; the Parkin prize (3400 francs), for work on the curative effects of carbon in cholera and other diseases; the Saintour prize (3000 francs), for work in physical science; the Henri de Parville prize (I50o francs), for osiginal worls on science ,or the popularisation of science; the Lonchampt prize (4000 francs), for a memoir on the diseases of man, animals, and plants from the point of view of the introduction of excess of mineral substances as the cause of these diseases; the Henry Wilde prize (one of 4000 francs, or two of 2000 francs, without distinction of nationality), for a tiscovery or work on astronomy, physics, chemistry, mineralogy, geology, or experimental mechanics; the Caméré prize (4000 francs), for a French engineer who has personally conceived, studied, and realised a work resulting in progress in the art of construction; the Gustave Roux prize (rooo francs, undivided), as recompense to a young French scientific worker; the Thorlet prize (1600 francs); the Lannelongue foundation (2000 francs), to one or two scientific men (or their widows or children) in needy circumstances; the Laplace prize of books, for the highest student leaving the Ėcole Polytechnique; the L. E. Rivot prize, to the four students leaving the Ecole Polytechnique and holding the first and second places in the two sections of the school; the Tremont foundation (1000 francs), for assisting works attaining an object useful and glorious for France; the Gegner foundation (400o francs), to assist a poor scientific man, already known for the quality of his work, to enable him to continue his researches; Jerome Ponti foundation ( 3500 francs), for the encouragement of mathematical science.

\section{The Bonaparte Funu.}

Grants from this fund are made for facilitating the researches of workers who have already given proof NO. 2465 , VOL. 98$]$ of their capability in original work, and who lack sufficient resources to undertake or pursue their investigations. Requests for grants may be made directly by the candidates or proposed by a member of the academy. The request should contain an exact description of the work proposed and indicate the sum necessary to carry it out. Twelve months after the receipt of a grant, a report must be sent giving details of expenditure and of the first results obtained; after two years a résumé of the work carried out with the aid of the grant must be forwarded. The whole of these reports will form a special publication under the title of "Recueil du Fonds Bonaparte."

\section{WORKSHOP METHODS OF OPTICAL TESTING.}

$A T$ the request of the Ministry of Munitions the A Optical Society held an exhibition of workshop methods of optical testing at King's College, Strand, on January $\mathrm{I}$, in order that by the interchange of work. shop methods of test, the production of optical instruments for naval and military use might be expedited. Amongst others, Messrs. Chance Bros. exhibited a method for the rapid approximate assessment of strain existing in glass. A plate of mica is cemented between glass plates, the mica being of such thickness as to give a phase difference in the two beams of one wave for sodium light. This plate therefore gives approximately the sensitive first order purple colour between crossed Nicols. According to the orientation of the specimen double refraction will be evident from the change of the purple colour to a tint of a lower or higher order. Each tint corresponds to a definite phase variation produced by the double refraction of the glass, and hence an estimation of the tints exhibited gives an estimation of the phase difference produced in a beam on passage through the glass. The colours given in conjunction with the wave plate are independent of the intensity of the light; thus greater uniformity in testing for bad annealing is obtained than by the use of crossed Nicols alone, where the sensitiveness of the tests depends largely on the intensity of the source of light.

Messrs. Adam Hilger exhibited a new apparatus and process for finishing prisms and lenses which are imperfect in consequence of non-homogeneous material or inaccurate surfaces. The apparatus consists of a modification of the Michelson interferometer, A beam of light is passed through the optical element under test in such a way as to produce a series of interference fringes which constitute what may be called a contour map of imperfections. This map can be drawn on one of the surfaces of the prism or lens; superfluous material is then removed by local polishing until light is transmitted as in a perfect optical element.

Prof. Herbert Jackson exhibited samples of glass which had undergone a weathering test, by submission to the action of steam in an autoclave. The condition of glass surfaces after a standard test is an index of the behaviour of the glass when subjected to normal atmospheric exposure.

The National Physical Laboratory exhibited the photometer used in testing the luminosity of radiumpainted dials. The dial under test is placed between two "artificial dials" illuminated by an electric lamp placed behind a suitable green filter; the candle-power of the lamp is varied by means of a resistance. The instrument is standardised by the use of a surface brightness photometer for various currents through the lamp. Samples of glass were also exhibited made from sands obtained in England, to replace sands hitherto obtained from the Continent. 